\title{
ORGANIC MATTER FRACTIONS AND SOIL FERTILITY UNDER THE INFLUENCE OF LIMING, VERMICOMPOST AND CATTLE MANURE
}

\author{
Renato Yagi ${ }^{1}$; Manoel Evaristo Ferreira ${ }^{1 *}$; Mara Cristina Pessôa da Cruz ${ }^{1}$; José Carlos Barbosa ${ }^{2}$ \\ ${ }^{l}$ UNESP/FCAV - Depto. de Solos e Adubos, Via de Acesso Prof. Paulo Donato Castellane s/n - 14884-900 - \\ Jaboticabal, SP - Brasil. \\ ${ }^{2}$ UNESP/FCAV - Depto. de Ciências Exatas. \\ *Corresponding author <evaristo@fcav.unesp.br>
}

\begin{abstract}
This work evaluates effects of cattle manure vermicompost in association with liming on soil fertility indexes. The experiment was carried out in greenhouse conditions, in pots containing samples of a Typic Hapludox, medium-textured soil. Five levels of vermicompost (equivalent to 0, 28, 42, 56, and $70 \mathrm{t} \mathrm{ha}^{-1}$, dry weight) and five liming levels (to raise base saturation to 20,30,40,50, and 60\%) were combined in a factorial scheme and samples were incubated for 180 days. Samples of the same soil received the equivalent to $70 \mathrm{t} \mathrm{ha}^{-1}$ of the cattle manure used to produce the vermicompost, and the same lime rates. Cattle manure was better than vermicompost to supply $\mathrm{K}$ and $\mathrm{Mg}$. Small differences in $\mathrm{P}$ supply were observed between the manures. The vermicompost increased the levels of $\mathrm{Ca}, \mathrm{pH}$, organic matter $(\mathrm{OM})$ and $\mathrm{CEC}$ more than the manure. C-humic acids decreased and C-humin increased with vermicompost application. With liming, Chumic acids decreased, but the total content of OM was not affected.
\end{abstract}

Key words: manure, $\mathrm{pH}$, fulvic acids, humic acids, humin

\section{FRAÇÕES ORGÂNICAS E FERTILIDADE DO SOLO SOB INFLUÊNCIA DE CALAGEM, VERMICOMPOSTO E ESTERCO DE CURRAL}

\begin{abstract}
RESUMO: Os efeitos do vermicomposto de esterco de curral associado à calagem em atributos da fertilidade do solo foram avaliados através de experimento em vasos empregando um Latossolo Vermelho, distrófico, textura média. Cinco doses do vermicomposto (equivalentes a $0 ; 28 ; 42 ; 56$ e $70 \mathrm{t} \mathrm{ha}^{-1}$, peso seco) e cinco doses de calcário (visando elevar a saturação por bases a: 20; 30; 40; 50 e 60\%) foram combinadas em esquema fatorial, sendo as amostras de solo incubadas por 180 dias. Para comparação entre o vermicomposto e o esterco de curral, amostras do mesmo solo receberam o equivalente a $70 \mathrm{t} \mathrm{ha}^{-1}$ do esterco de curral que originou o vermicomposto e as cinco doses de calcário listadas anteriormente. Através do cálculo do Índice de Eficiência Agronômica, foi verificado que o potencial de fornecimento de $\mathrm{K}$ e de $\mathrm{Mg}$ pelo esterco é maior do que o do vermicomposto, e que o de $\mathrm{P}$, é semelhante. $\mathrm{O}$ vermicomposto aumentou os teores de $\mathrm{Ca}^{2+}$ e de matéria orgânica (MO), os valores de $\mathrm{pH} \mathrm{em} \mathrm{CaCl}_{2}$ e a CTC a pH 7. Com o aumento das doses de vermicomposto houve diminuição do $\mathrm{C}$-ácidos húmicos e aumento do $\mathrm{C}$-humina e com a calagem o $\mathrm{C}$-total não aumentou mas houve diminuição do C-ácidos húmicos.

Palavras-chave: adubos orgânicos, pH, ácidos fúlvicos, ácidos húmicos, humina
\end{abstract}

\section{INTRODUCTION}

Soil organic matter (OM) contains two large groups of substances - the non-humic and the humic compounds. The first group is represented by substances with greater bioavailability and known chemical properties, such as polysaccharides and sugars, proteins and amino acids, lipids and fatty acids, waxes, pigments and other substances of low molecular weight (Schnitzer, 1991; Stevenson, 1994; Lobartini \& Orioli, 1996). Humic substances (HS) constitute a heterogeneous, dark-colored and amorphous mixture of substances with high molecular weight (Stevenson, 1994). However, there has been in- creasing evidence that HS consist of associations of relatively small, heterogeneous molecules, bound together by weak dispersive forces (Piccolo, 2001) and show greater chemical stability and lower bioavailability than non-humic substances (Lobartini \& Orioli, 1996).

According to their solubility traits, HS are divided into humic acid (HA), soluble in alkaline medium; fulvic acid (FA), soluble in both alkaline and acid media; and humin $(\mathrm{H})$, insoluble in both media (Schnitzer, 1991; Stevenson, 1994). The humin fraction represents the largest amount in humus, both in soils of tropical regions and soils under temperate climate conditions. This is a highly condensed fraction (more than $60 \% \mathrm{C}$ ), closely linked to 
the soil's mineral fraction, and cannot be separated even in alkaline medium (Marschner \& Wilczynski, 1991; Melo et al., 1994; Nascimento et al., 1988; Rosales et al., 1999; Stevenson, 1986; Yagi et al., 2000).

HS represent between $65 \%$ and $80 \%$ of the total OM and its active fraction (Schnitzer, 1991; Piccolo, 2001). The high cation exchange capacity (CEC) of these substances is attributed mainly to carboxylic and phenolic radicals, and increases as the $\mathrm{pH}$ increases (Hayes \& Malcolm, 2001). According to Stevenson (1986), FA and HA present between 6,400 and 14,200 and between 5,600 and $8,900 \mathrm{mmol}_{\mathrm{c}} \mathrm{kg}^{-1}$ total acidity from phenolic and carboxylic radicals, respectively. Differences between amounts of radicals in the two fractions are related to the fact that FA has greater amounts of $\mathrm{O}$ and smaller amounts of $\mathrm{C}$ than HA, despite the lower molecular weight of the first. In addition, oxygen in FA is almost totally in the form of $\mathrm{COOH}, \mathrm{O}-\mathrm{H}$ and $\mathrm{C}=\mathrm{O}$ groups, while in $\mathrm{HA}$, substantial part of the $\mathrm{O}$ occurs as structural component (ether or ester bonds).

Applying organic fertilizers elicit increasing OM and positively change other chemical characteristics associated with soil fertility, such as CEC, $\mathrm{pH}$ and nutrient availability (Mazur et al., 1983; Ferreira \& Cruz, 1992; Alves et al., 1999). In addition, the increase in $\mathrm{pH}$ can affect the dynamics of soil organic matter fractions, leading to a depolymerization of HA and to a small increase in FA (Araujo et al., 1995).

Significant increases in $\mathrm{OM}$ and $\mathrm{C}$ contents in all OM fractions were observed by Rosales et al. (1999) with the application of $40 \mathrm{~m}^{3}$ compost, either combined or not with mineral fertilizers. Eleven years later, the OM contents increased between 15.3 and $19.8 \mathrm{~g} \mathrm{~kg}^{-1}$, reaching $20.8 \mathrm{~g} \mathrm{~kg}^{-1}$ when compost and mineral fertilization were combined. The application of compost accompanied by mineral fertilization supplied greater amounts of HA and FA to the surface layer.

In Brazil, cattle manure is the most frequently utilized organic fertilizer. In recent years, supplying cattle manure vermicompost has become a profitable activity for many producers. However, no available research results would allow a conclusion as to whether using this product is more advantageous than using manure. This work was therefore developed to compare the effects of cattle manure and vermicompost, together with liming, on soil fertility, especially regarding the quality of the generated organic matter.

\section{MATERIAL AND METHODS}

The experiment was conducted in a greenhouse on samples from the layer $0-0.20 \mathrm{~m}$ of a medium-textured, Typic Hapludox, collected in a forested area in

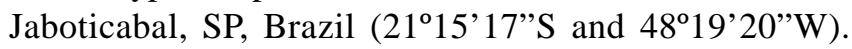
The soil's preliminary chemical analysis (Raij et al., 1987) presented: $\mathrm{P}$ resin $=3 \mathrm{mg} \mathrm{dm}^{-3} ; \mathrm{OM}=21 \mathrm{~g} \mathrm{dm}^{-3} ; \mathrm{pH}$ in $\mathrm{CaCl}_{2} 0.01 \mathrm{~mol} \mathrm{~L}^{-1}=4.0 ; \mathrm{K}=0.5 \mathrm{mmol}_{\mathrm{c}} \mathrm{dm}^{-3} ; \mathrm{Ca}=3$ $\mathrm{mmol}_{\mathrm{c}} \mathrm{dm}^{-3} ; \mathrm{Mg}=1 \mathrm{mmol}_{\mathrm{c}} \mathrm{dm}^{-3} ; \mathrm{Al}=6 \mathrm{mmol}_{\mathrm{c}} \mathrm{dm}^{-3}$; $\mathrm{H}+\mathrm{Al}=47 \mathrm{mmol}_{\mathrm{c}} \mathrm{dm}^{-3} ; \mathrm{CEC}$ at $\mathrm{pH} 7.0=52 \mathrm{mmol}_{\mathrm{c}}^{\mathrm{c}} \mathrm{dm}^{-3}$; and base saturation $=9 \%$.

Trials were set up in a completely randomized design, in a $5 \times 5$ factorial scheme (five vermicompost rates $x$ five liming rates), with two replicates. The vermicompost utilized was obtained from dairy cattle manure under confinement. The lime rate factor, obtained by using $\mathrm{CaCO}_{3}$ and magnesium hydroxycarbonate (Ca: $\mathrm{Mg}$ ratio of $3: 1$ ), corresponded to rates necessary to obtain base saturation indexes equal to $20 ; 30 ; 40 ; 50$ and $60 \%$. The vermicompost factor utilized rates of $0 ; 28 ; 42$; 56 and $70 \mathrm{t} \mathrm{ha}^{-1}$. The cattle manure $70 \mathrm{t} \mathrm{ha}^{-1}$ rate (same manure utilized to produce the vermicompost), combined with the same lime rates $(\mathrm{V} \%=20 ; 30 ; 40 ; 50$; and 60), was used in comparison with the $70 \mathrm{tha}^{-1}$ vermicompost rate.

The organic fertilizers were air-dried, ground, passed through a $2 \mathrm{~mm}$ sieve and chemically characterized (C, N, P, K, Ca, Mg, Cu, Fe, Mn, and Zn), according to Kiehl (1985). The products (organic fertilizers and lime) were mixed with $1 \mathrm{dm}^{3}$ soil and transferred to aluminum pots covered with newspaper sheets. The experiment was conducted for 180 days, and the soil was watered to $60 \%$ of its water retention capacity.

At the end of the incubation period the soil was sampled to evaluate its chemical attributes, and to perform soil OM fractioning (Raij et al., 1987; Stevenson, 1986). CEC at pH 7.0 was determined by the direct method (Glória et al., 1965), as a replacement for the sum of exchangeable $\mathrm{K}^{+}, \mathrm{Ca}^{2+}$ and $\mathrm{Mg}^{2+}$ contents, and potential acidity $(\mathrm{H}+\mathrm{Al})$ (Raij et al., 1987). This procedure was adopted because the experiment was carried out in a closed system, without water percolation, and salt accumulation occurred because of mineralization of the organic fertilizers and OM, which could lead to an overestimation of the calculated CEC values.

The scheme proposed by Stevenson (1986) was followed for OM fractioning, except with regard to the water soluble carbon fraction extraction, previously done by treating the sample with a $\mathrm{NaOH} 0.1 \mathrm{~mol} \mathrm{~L}^{-1}$ solution. Extraction procedure was based on Dabin (1976), and a mass equivalent to $10 \mathrm{~cm}^{3}$ of soil was used. Laboratory procedures are described ahead:

Water-soluble organic matter: Fifty $\mathrm{mL}$ deionized water were added to a centrifuge tube $(250 \mathrm{~mL})$ containing $10 \mathrm{~cm}^{3}$ of the sample; suspension was shaken for $30 \mathrm{~min}$ at $150 \mathrm{rpm}$, in horizontal shaker. Samples were centrifuged for $15 \mathrm{~min}$ at $10,000 \mathrm{rpm}$, and the supernatant was filtered through Whatman n.1 filter paper.

Humic substances: The sediment in the centrifuge tube was resuspended with $100 \mathrm{~mL}$ of a $\mathrm{NaOH} 0.1 \mathrm{~mol} \mathrm{~L}^{-1}$ so- 
lution. The suspension was shaken for $60 \mathrm{~min}$ at $150 \mathrm{rpm}$ and centrifuged for $10 \mathrm{~min}$ at $8,000 \mathrm{rpm}$. The supernatant was transferred to a $200 \mathrm{~mL}$ volumetric flask. The procedure was repeated with $50 \mathrm{~mL}$ of a NaOH $0.1 \mathrm{~mol} \mathrm{~L}^{-1}$ solution, followed by $30 \mathrm{~min}$ shaking. The supernatant was transferred to the same volumetric flask and the volume was completed with deionized water. Part of the volume obtained was utilized $(100 \mathrm{~mL})$ for FA and HA separation, and the rest was used to determine carbon content in the humic fractions.

Fulvic acids fraction: One hundred $\mathrm{mL}$ of the HS fraction were pipetted to a centrifuge tube. Concentrated $\mathrm{H}_{2} \mathrm{SO}_{4}$ was added to lower the $\mathrm{pH}$ to 2.0 , manually shaken. The suspension was submitted to centrifugation for $10 \mathrm{~min}$ at $5,000 \mathrm{rpm}$. The supernatant contained the FA fraction, and the precipitate contained the HA fraction. Carbon was determined in the HS and HA fractions; $\mathrm{C}$ in the FA fraction was obtained by difference between those two fractions.

Humic acids fraction: After fraction FA was obtained, $25 \mathrm{~mL}$ of a $\mathrm{NaOH} 0.1 \mathrm{~mol} \mathrm{~L}^{-1}$ solution were added to the precipitate in the centrifuge tube; the precipitate was solubilized by manual shakening. The fraction was quantitatively transferred to a $50-\mathrm{mL}$ volumetric flask with deionized water and the volume was completed to capacity.

Humin: The sediment that remained in the centrifuge tube after HS was fully transferred to a Petri dish and oven dried at $65^{\circ} \mathrm{C}$. After drying, the residue mass was obtained and the material was ground with mortar for later determination of carbon content.

The colorimetric method was utilized for carbon quantification in the OM fractions. Two linear calibration graphs were prepared: one using a glucose solution to convert the absorbance data into carbon in the water soluble, HS and HA fractions, and the other by adapting the procedure utilized in the South Dakota modified method (Quaggio \& Raij, 1979), to convert the humin fraction data.

Solutions with 0 to $600 \mathrm{mg} \mathrm{L}^{-1} \mathrm{C}$ were used to prepare the glucose linear calibration graph. Four-mL aliquots of each standard and a $10-\mathrm{mL}$ aliquot of a $\mathrm{Na}_{2} \mathrm{Cr}_{2} \mathrm{O}_{7} 0.667 \mathrm{~mol} \mathrm{~L}^{-1}+\mathrm{H}_{2} \mathrm{SO}_{4} 5 \mathrm{~mol} \mathrm{~L}^{-1}$ solution were transferred to a $250-\mathrm{mL}$ Erlenmeyer flask. The flask, with a test tube containing water attached to its neck, was heated on a plate at $100^{\circ} \mathrm{C}$ for $7 \mathrm{~min}$. After cooling, the reading of extract's absorbance was obtained in a colorimeter at $650 \mathrm{~nm}$. The absorbance for organic matter fractions was obtained in $4 \mathrm{~mL}$ aliquots of the extract, which received the same treatment as the glucose standards.

To obtain the linear calibration graph for humin, the humic substances fraction were extracted and discarded, from 12 standard soils in use at the laboratory, and the residue-containing humin was obtained. Carbon in the humin fraction was determined by the Walkley \& Black method. In a different series of the same residues, the absorbance was determined from extracts obtained by the modified South Dakota method (Quaggio \& Raij, 1979). Based on the C-humin contents data obtained by the Walkley \& Black method, and on the measured absorbance values, the regression equation utilized to convert absorbance values of the samples into carbon concentration of the humin fraction was calculated. For Chumin determination, $1 \mathrm{~cm}^{3}$ of soil was utilized. Based on the mass of $1 \mathrm{~cm}^{3}$ humin, from the total humin mass obtained from each sample and on the mass of $10 \mathrm{~cm}^{3}$ of soil used to extract the fractions, it was possible to express C-humin as $\mathrm{g} \mathrm{dm}^{-3}$.

The effects of vermicompost and liming on the soil's chemical attributes were evaluated through analysis of variance by the $\mathrm{F}$ test and, when significance occurred, the effects were partitioned by polynomial regression. The agronomic efficiency index (AEI) was determined for $\mathrm{P}, \mathrm{K}, \mathrm{Ca}, \mathrm{Mg}, \mathrm{OM}$ and $\mathrm{CEC}$ data by the following equation, adapted from Raij (1991):

$$
\mathrm{AEI}=\frac{\mathrm{Y} \text { verm }-\mathrm{Y} \text { ctrl }}{\mathrm{Y} \text { mnre }-\mathrm{Y} \text { ctrl }} \times 100
$$

$\mathrm{Y}=$ soil fertility attribute (OM, CEC at $\mathrm{pH} 7.0$, resin-extracted $\mathrm{P}$, etc.); verm $=\mathrm{Y}$ values in the treatment that received $70 \mathrm{t} \mathrm{ha}^{-1}$ vermicompost; $\mathrm{ctrl}=\mathrm{Y}$ values in the control; mnre $=\mathrm{Y}$ values in the treatment that received $70 \mathrm{t} \mathrm{ha}^{-1}$ cattle manure. The evaluation of liming and vermicompost effects on the $\mathrm{C}$ content in the $\mathrm{OM}$ fractions was made in compliance with the same statistical procedure described for the soil's chemical attributes; comparison between manure and vermicompost was done by Tukey test $(P<0.05)$.

\section{RESULTS AND DISCUSSION}

\section{Effects of organic fertilization and liming on soil fer- tility}

Characterization of the organic fertilizers utilized revealed that the vermicompost became poorer in $\mathrm{K}$ and richer in $\mathrm{Cu}, \mathrm{Fe}, \mathrm{Mn}$ and $\mathrm{Zn}$, in comparison to cattle manure (Table 1). Losses by leaching justify the decrease in $\mathrm{K}$ and, in the case of micronutrients, enriching is explained mainly by contamination by soil from the place where the vermicomposting was done, and by the relative concentration that occurred as a consequence of volume reduction at the vermicomposting stage. With the application of $70 \mathrm{tha}^{-1}$ manure, the amounts incorporated to the soil would be, in $\mathrm{kg} \mathrm{ha}^{-1}, 1,890 \mathrm{~N} ; 840 \mathrm{P} ; 1,190 \mathrm{~K}$; $1,190 \mathrm{Ca}$ and $560 \mathrm{Mg}$; with the application of $70 \mathrm{t} \mathrm{ha}^{-1}$ vermicompost, those amounts would be 1,$680 ; 910 ; 350$; 1,750 and $420 \mathrm{~kg} \mathrm{ha}^{-1}$ respectively. 
Effects of vermicompost and liming on soil fertility attributes are depicted in Table 2 . The contents of available $\mathrm{P}$ and exchangeable $\mathrm{K}, \mathrm{Ca}$ and $\mathrm{Mg}$ increased linearly as the vermicompost rates increased, regardless of liming (Figure 1a, b, c, d). The agronomic efficiency index (AEI) was calculated to compare the highest vermicompost rate to the application of the same rate of manure. Vermicompost was more efficient than cattle manure in supplying exchangeable calcium (AEI $=139 \%)$ and less efficient in increasing the exchangeable potassium $(\mathrm{AEI}=22 \%)$ and magnesium $(\mathrm{AEI}=$ $68 \%$ ) contents, reflecting the tendency of the original content concentrations of these elements in the utilized materials. The contribution of manure and vermicompost to available $\mathrm{P}$ in the soil was similar (AEI $=108 \%)$.

Organic fertilization, in association or not with liming, provided increases in soil $\mathrm{pH}$ (Figure 2). By using the isoline chart, it is possible to estimate the rate of substitution of lime by vermicompost to obtain equivalent $\mathrm{pH}$ values. As an example, a $\mathrm{pH}$ value around 5.6 can be obtained by applying $2 \mathrm{t} \mathrm{ha}^{-1}$ lime (rate necessary to obtain V\% $=47 \%$ under the conditions of the experiment) and $60 \mathrm{t} \mathrm{ha}^{-1}$ vermicompost, or $2.4 \mathrm{t} \mathrm{ha}^{-1}$ lime (V\% $=55 \%$ ) with $50 \mathrm{t} \mathrm{ha}^{-1}$ vermicompost. Abreu Jr. et al. (2000) observed a 30 to $50 \%$ decrease in potential acidity in a group of 20 acid soils and a substitution rate of $2 \mathrm{t} \mathrm{ha}^{-1}$ lime or higher, for $60 \mathrm{tha}^{-1}$ urban waste compost.

Organic fertilization increases soil $\mathrm{pH}$ supplying bases, forming alkaline humates during the process of decomposition and synthesis of these residues, and by $\mathrm{Al}$ complexing through organic molecules, such as FA (Mazur et al., 1983; Ferreira \& Cruz, 1992) and other low molecular weight acids (Hue et al., 1986). With the equivalent to $70 \mathrm{tha}^{-1}$ vermicompost and cattle manure, the $\mathrm{pH}$ value in the treatment with liming to raise $\mathrm{V}$ to $20 \%$, which was 4.1 , increased to 5.3 and 4.9 , respectively ( $\mathrm{pH}$ values that would be obtained with liming for $\mathrm{V}=60 \%$, without organic fertilization). In addition, the highest $\mathrm{pH}$ (5.8) was observed in association with liming for $\mathrm{V}$ equal to 50 or $60 \%$ and $70 \mathrm{t} \mathrm{ha}^{-1}$ vermicompost (Figure 3).

OM contents were only affected by the application of vermicompost (Table 2), increasing linearly (Figure 1e). In addition, the AEI for vermicompost, as compared to cattle manure, was $180 \%$, indicating that the vermicompost was $80 \%$ more efficient to increase OM than manure. Therefore, $70 \mathrm{t} \mathrm{ha}^{-1}$ of cattle manure would be necessary to produce the same amount of OM generated by $39 \mathrm{t} \mathrm{ha}^{-1}$ of vermicompost. Manure is a material in decomposition. Therefore, when manure is applied to the soil, it continues loosing $\mathrm{CO}_{2}$ to the atmosphere until the more labile $\mathrm{OM}$ is decomposed. So when equivalent amounts of compost and manure are applied to the soil, it is expected that the compost will incorporate more OM to the soil, because of the greater OM stability in the compost.

There was interaction $(P<0.01)$ between fertilization with vermicompost and liming, with respect to the effect of these treatments on CEC values (Table 2). The increase in CEC with the vermicompost rates was linear for $\mathrm{V}=20 ; 30 ; 50$ and $60 \%$, and quadratic for $\mathrm{V}=40 \%$ (Figure 4). Notwithstanding, when the effect of liming was partitioned within each vermicompost rate, regressions were non-significant. Vermicompost and manure rates of $70 \mathrm{t} \mathrm{ha}^{-1}$ modified the CEC values from $44 \mathrm{mmol}_{\mathrm{c}} \mathrm{dm}^{-3}$ to 62 and $57 \mathrm{mmol}_{\mathrm{c}} \mathrm{dm}^{-3}$, respectively. Significant increases in CEC at pH 7.0 were obtained by Melo et al. (1994) with the application of sewage sludge in a soil planted with sugarcane. The comparison of the effect of vermicompost on CEC, in relation to manure, was done by the AEI, which reached $145 \%$, indicating that the vermicompost was $45 \%$ more efficient than manure in increasing the soil's CEC. This greater efficiency is associated with the greater production of functional groups during the vermicomposting process, which are

Table 1 - Chemical characterization of organic fertilizers utilized.

\begin{tabular}{|c|c|c|c|c|c|c|c|c|c|c|}
\hline Organic fertilizer & $\mathrm{C}$ & $\mathrm{N}$ & $\mathrm{P}$ & $\mathrm{K}$ & $\mathrm{Ca}$ & $\mathrm{Mg}$ & $\mathrm{Fe}$ & $\mathrm{Cu}$ & $\mathrm{Mn}$ & $\mathrm{Zn}$ \\
\hline & (n) & -- & -- & $\mathrm{g} \mathrm{kg}$ & . & & $\ldots$ & \multicolumn{3}{|c|}{ - $\mathrm{mg} \mathrm{kg}^{-1} \ldots \ldots$} \\
\hline Cattle manure & 330 & 27 & 12 & 17 & 17 & 8 & 8 & 46 & 337 & 105 \\
\hline Vermicompost & 158 & 24 & 13 & 5 & 25 & 6 & 28 & 107 & 649 & 197 \\
\hline
\end{tabular}

Table 2 - Analysis of variance of the effects of vermicompost rates and liming levels on soil attributes.

\begin{tabular}{|c|c|c|c|c|c|c|c|}
\hline Factor & $\mathrm{P}$ & $\mathrm{OM}$ & $\mathrm{pH}$ & $\mathrm{K}$ & $\mathrm{Ca}$ & $\mathrm{Mg}$ & CEC \\
\hline & -------1 & 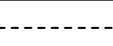 & & $\ldots-F$ & (n-1 & 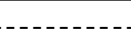 & 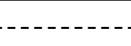 \\
\hline Liming (C) & $0.8^{\mathrm{ns}}$ & $0.8^{\mathrm{ns}}$ & $310.0 * *$ & $1.3^{\mathrm{ns}}$ & $25.3 * *$ & $21.3 * *$ & $4.4 * *$ \\
\hline Vermicompost (V) & $209.9 * *$ & $21.1 * *$ & $841.5^{* *}$ & $853.9 * *$ & $132.6 * *$ & $149.9 * *$ & $118.5^{* *}$ \\
\hline $\mathrm{C} \times \mathrm{V}$ interaction & $0.8^{\mathrm{ns}}$ & $0.8^{\mathrm{ns}}$ & $4.5^{* *}$ & $1.1^{\mathrm{ns}}$ & $0.8^{\text {ns }}$ & $0.8^{\mathrm{ns}}$ & $3.3 * *$ \\
\hline $\mathrm{CV} \%$ & 15.7 & 10.9 & 0.9 & 4.3 & 10.8 & 11.3 & 6.4 \\
\hline
\end{tabular}

${ }^{\mathrm{ns}}$ and ${ }^{* *}$ non significant and significant at $1 \%$, respectively. 
responsible for the production of surface charges, as verified by Jiménez \& Garcia (1992) during the composting process of urban residues.

\section{Liming effect on the soil's organic matter fractions}

The water-soluble $\mathrm{C}$ fraction (C-WS) represented less than $1 \%$ of the total $\mathrm{C}$ in the soil. The carbon content in this fraction was only affected by liming (Table 3), and no statistical significance was obtained for the linear and quadratic regression models. Kreutzer (1995) obtained an increase in organic carbon content dissolved with liming in a spruce stand with 80 years of age, in Norway. The carbon content in the humic substances (C-HS) was affected by liming and fertilization with vermicompost (Table 3). Through regression analysis, a significant and negative correlation between the $\mathrm{C}$ content in this frac-
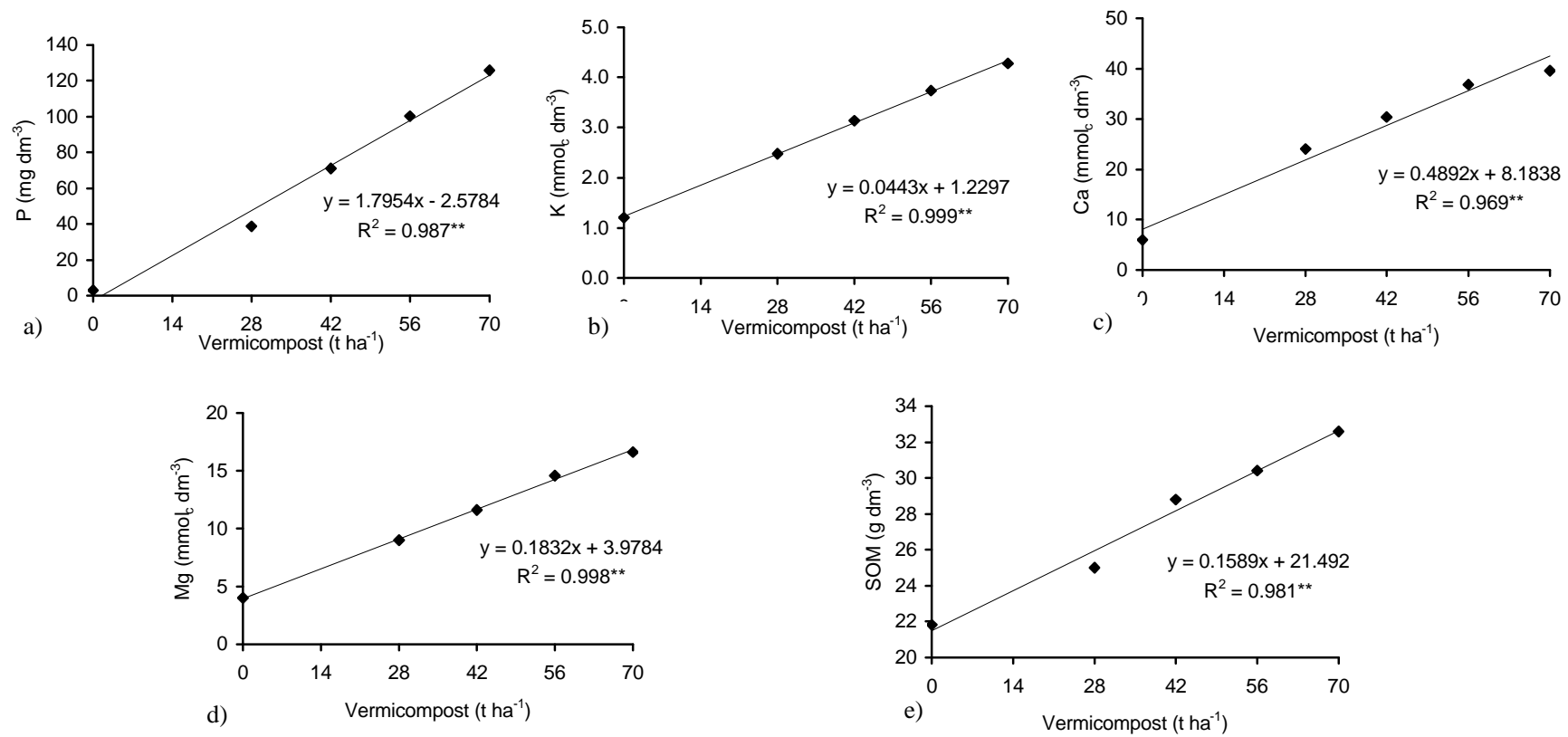

Figure 1 - Soil fertility attributes as a function of vermicompost rates. ${ }^{* *}$ significant at $1 \%$.

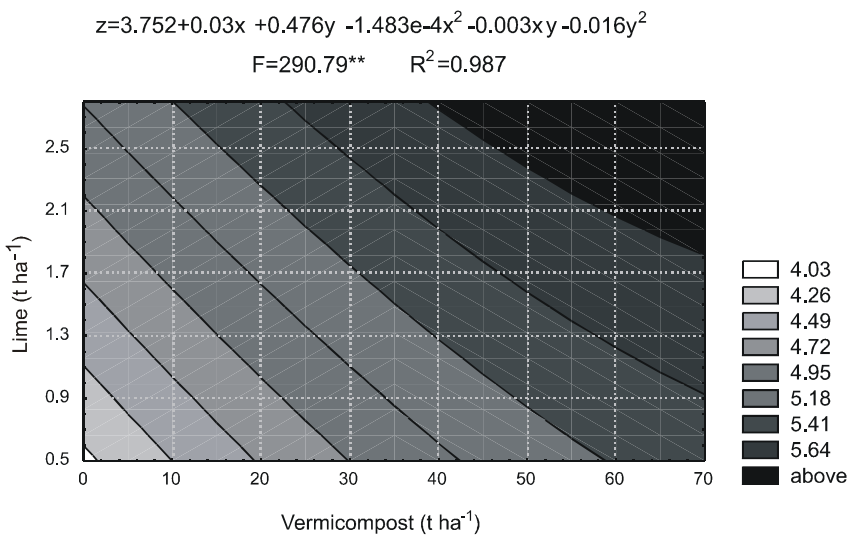

Figure 2 - Isolines for $\mathrm{pH}$ in $\mathrm{CaCl}_{2}$ as a function of vermicompost and lime rates. ${ }^{* *}$ significant at $1 \%$.

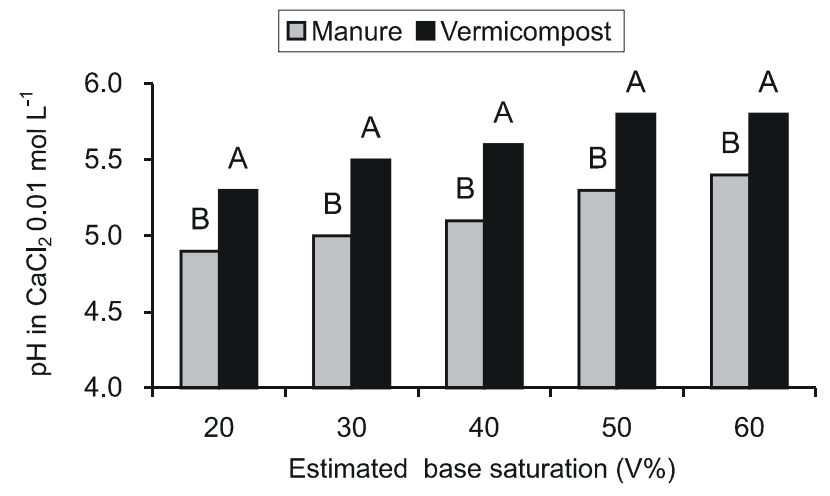

Figure 3 - Comparison between effects of application of $70 \mathrm{t} \mathrm{ha}^{-1}$ vermicompost and manure, on soil $\mathrm{pH}$, in all liming levels. Distinct letters indicate significant effect by Tukey test $(P<0.05)$.

Table 3 - Analysis of variance of effects of vermicompost rates and liming levels on soil's organic matter fractions.

\begin{tabular}{lcccccc}
\hline Factor & C-WS & C-HS & C-HA & C-FA & C-H & C total \\
\hline Liming (C) & $2.8^{*}$ & $5.1^{* *}$ & $8.3^{* *}$ & $1.5^{\text {ns }}$ & $1.2^{\text {ns }}$ & $1.5^{\text {ns }}$ \\
Vermicompost (V) & $0.93^{\text {ns }}$ & $2.9^{*}$ & $4.9^{* *}$ & $0.9^{\text {ns }}$ & $53.3^{* *}$ & $37.8^{* *}$ \\
C x V interaction & $1.6^{\text {ns }}$ & $1.1^{\text {ns }}$ & $1.8^{\text {ns }}$ & $0.9^{\text {ns }}$ & $0.7^{\text {ns }}$ & $1.6^{\text {ns }}$ \\
\hline CV\% & 2.4 & 18.0 & 14.4 & 57.0 & 10.2 & 7.5 \\
\hline
\end{tabular}

ns, ${ }^{*}$ and ${ }^{* *}$ non significant and significant at 5 and 1\%, respectively. C: carbon; WS: water soluble; HS: humic substances; HA: humic acids; FA: fulvic acids; $\mathrm{H}$ : humin; total: total carbon content. 
tion and the liming levels was observed, and the best fit was obtained with the linear regression model (Figure 5a).

When the effects of $\mathrm{pH}$ on the humic acids $(\mathrm{C}$ HA) and fulvic acids (C-FA) fractions are disregarded, the proportion of carbon relative to the total ranged from 26 to $17 \%$ and from 17 to $12 \%$, respectively. The highest values for each fraction were obtained with treatments that did not receive vermicompost, and the smallest values were observed in treatments which received the equivalent to $70 \mathrm{t} \mathrm{ha}^{-1}$ vermicompost.

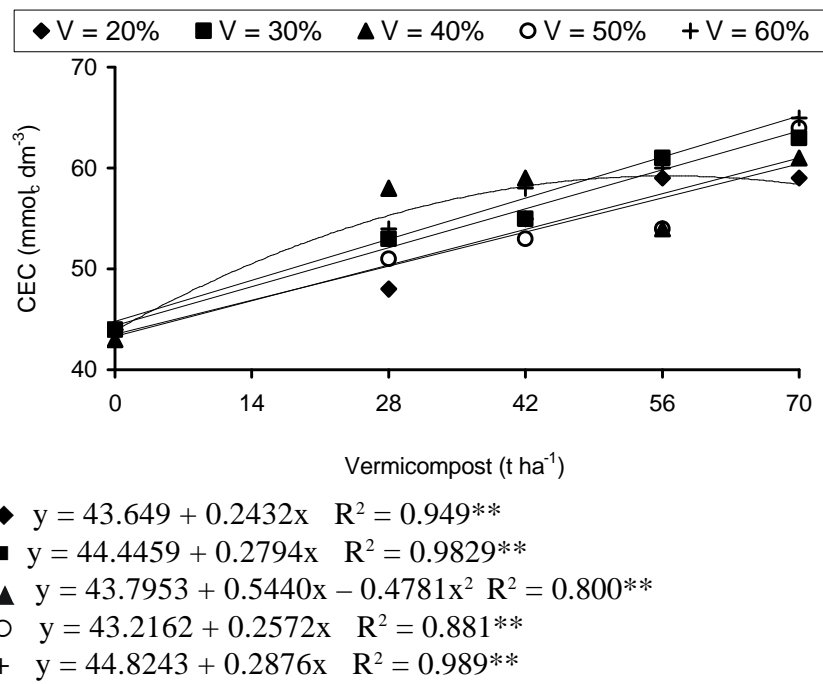

Figure 4 - CEC as a function of vermicompost rates, in each liming level. ${ }^{* *}$ significant at $1 \%$.
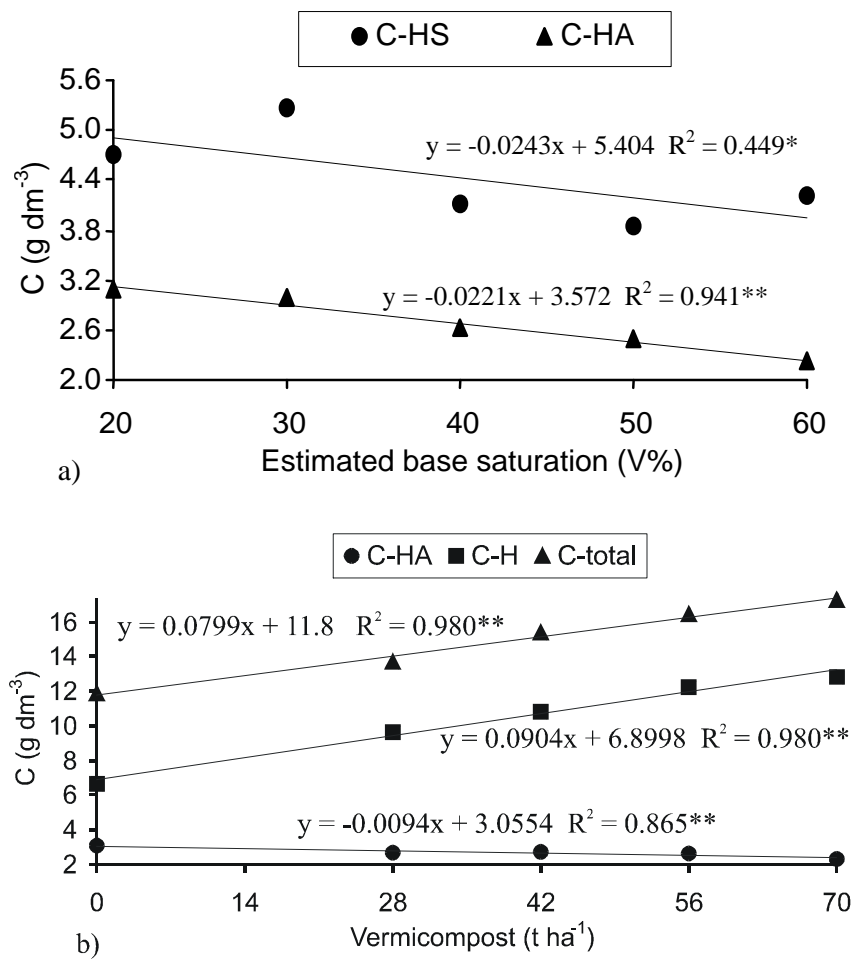

Figure 5 - Carbon in the organic matter fractions as a function of liming a) and vermicompost b). * and **significant at $5 \%$ and $1 \%$, respectively.
Liming decreased the $\mathrm{C}$ content in the HA fraction (Figure 5a), but did not affect the $\mathrm{C}$ contents in the FA fraction, probably because of interconversions between the less polymerized fractions, resulting in high variability of the results (Melo et al., 1994). Silva et al. (2000) observed an increase in total $\mathrm{C}$ content and a reduction in $\mathrm{C}$ in the FA and HA fractions in a Red Latosol under a citrus grove, resulting from liming. The decrease in C-HA contents might be related to the presence of oxides which, however not determined in that study, are usually abundant in latosols. In oxide and kaolinite-rich tropical soils, the C-HA fraction can be more easily decomposed than the C-FA fraction, giving rise to more reactive fractions, easily consumed by microorganisms (Mendonça, 1995), since the adsorption of OM to oxides is influenced by carboxylic groups, more abundant in the FAs (Greenland, 1971; Varadachari et al., 1995; Lobartini \& Orioli, 1996).

Therefore, in very clayey latosols, a great part of the reactive FA sites would be blocked by kaolinite as well as $\mathrm{Fe}$ and $\mathrm{Al}$ oxides and hydroxides, by the ligand exchange reactions, thus forming strong bonds with their negative charges, making them more resistant to decomposition than HAs (Greenland, 1971; Varadachari et al., 1995). On the other hand, Tombácz (1999) mentions that the aggregation between HA molecules and the surface of mineral particles depends upon an increase in $\mathrm{pH}$, and that dissociation in such molecules is difficulted when they are aggregated, because of their hydrophobic traits.

The decrease in exchangeable $\mathrm{Al}^{3+}$ with liming may also be associated to a decrease in C-HA. In the soil under study, the exchangeable $\mathrm{Al}^{3+}$ in treatments without liming and without organic fertilization was $6 \mathrm{mmol}_{\mathrm{c}} \mathrm{dm}^{-3}$, a mean level (Ribeiro et al., 1999). Liming decreases the forms of exchangeable aluminum and those associated with organic molecules, and increases the calcium content associated with the OM (Mendonça \& Rowell, 1994). For this reason, it promotes destabilization of the organic molecules, making them more susceptible to microbial attacks, since the complexes of $\mathrm{Ca}$ with the $\mathrm{OM}$ are more unstable than those of OM with $\mathrm{Al}$ (Canellas et al., 1999).

It is expected that liming will bring an increase in microbial activity and a decrease in the OM content in the soil (Curtin et al., 1998). Marschner \& Wilczynsky (1991) reported that, while the carbon content in a soil under a Pinus forest remained unchanged in a treatment without acidity correction, in areas where liming had been performed there was a $10 \%$ decrease in the content of $\mathrm{C}$ after four years of evaluation. However, the effect of liming may vary with time and environment conditions, such as soil temperature and moisture (Kreutzer, 1995), which might justify the sustained total $\mathrm{C}$ contents, obtained both by direct determination and by sum of fractions.

The C-H fraction was responsible for about 70 to $75 \%$ of total $\mathrm{C}$, except in the treatment that did not receive organic fertilizer, in which this percentage decreased to 
56\%. C-H was not affected by soil $\mathrm{pH}$, and because it represents the major part of total $\mathrm{C}$, the same effect was observed for total $\mathrm{C}$ obtained by sum of fractions (Table 3 ).

\section{Organic fertilization effect on soil's organic matter fractions}

Organic fertilization with vermicompost led to a linear decrease in $\mathrm{C}$ content in the $\mathrm{HA}$ fraction and to a linear increase in total $\mathrm{C}$ and in the $\mathrm{C}-\mathrm{H}$ fraction (Figure $5 b)$. In addition to being related to the increase in $\mathrm{pH}$ caused by liming and by the addition of vermicompost, the decrease in C-HA content could also be associated with the increase in $\mathrm{C}-\mathrm{H}$ content. The increase in $\mathrm{C}-\mathrm{H}$ contents was correlated $(P<0.01)$ with the decrease in the contents of C-HA $(\mathrm{y}=17.064-2.463 \mathrm{x}, \mathrm{r}=-0.536)$.

The humification rate (C-HS/C-total), when liming is disregarded, was 0.25 for vermicompost treatments and 0.30 for manure treatments, indicating a greater proportion of less polymerized carbon compounds when manure is utilized. Extrapolating the results to a layer between 0 and $20 \mathrm{~cm}$ in one hectare, the difference between fertilizers would be an additional $1.08 \mathrm{t} \mathrm{ha}^{-1} \mathrm{C}-\mathrm{HS}$ when manure is applied, and an additional $2.88 \mathrm{t} \mathrm{ha}^{-1} \mathrm{C}-\mathrm{H}$ when vermicompost is applied. These results support assertion by Lal (2001), that the humification efficiency is usually greater for composted material as compared to a fresh one.
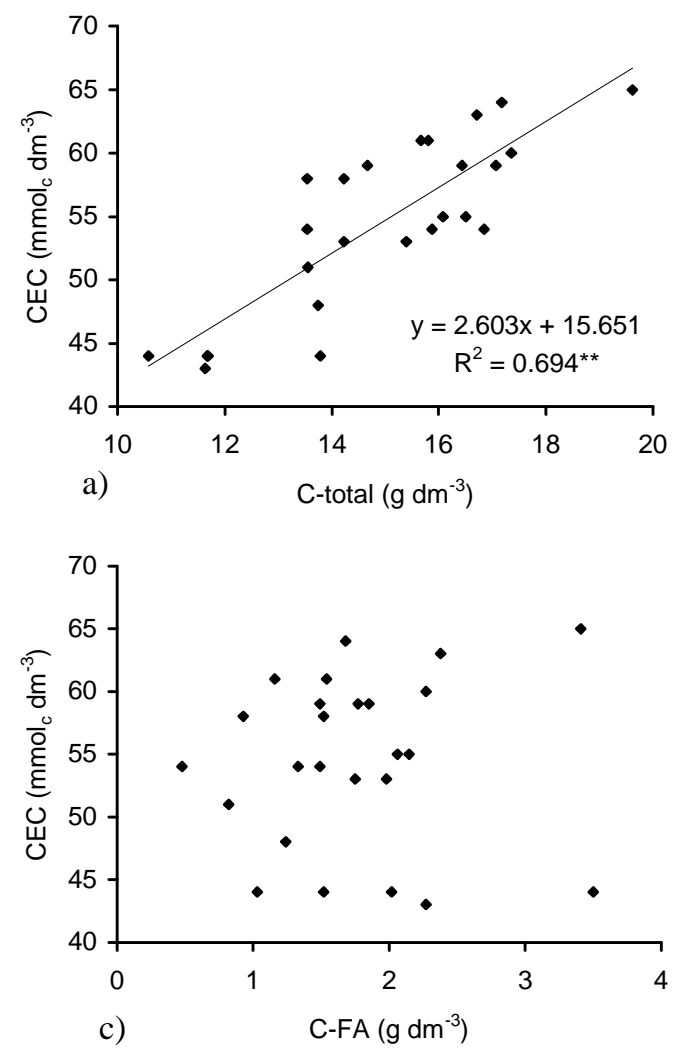

Relations between the soil's OM fractions (C-FA and $\mathrm{C}-\mathrm{HA}$ ) and $\mathrm{CEC}$ at $\mathrm{pH} 7.0$ are presented in Figure 6 . Results obtained with the application of vermicompost were utilized for the calculations. Since there was a decrease in C-HA with organic fertilization and liming, the relationship between this form of carbon and CEC at $\mathrm{pH}$ 7.0 was negative. Because of the variability in the C-FA fraction, no correlation was obtained between it and CEC at $\mathrm{pH}$ 7.0, even though this form of carbon shows greater concentration of radicals responsible for the exchange capacity (Greenland, 1971; Stevenson, 1994). On the other hand, the soil's CEC increased linearly with the increase in C-H. In most treatments, as already mentioned, the organic $\mathrm{C}$ associated with this fraction represented about $70 \%$ of the total, and an increase in $\mathrm{C}-\mathrm{H}$ was observed under organic fertilization. These data agree with those presented by Melo et al. (1994), who observed that among the OM fractions, humin was the fraction most strongly correlated with CEC $(r=0.59)$.

There was no difference between the application of $70 \mathrm{t} \mathrm{ha}^{-1}$ manure or vermicompost, in each liming condition, as to the contents of C-HS and $\mathrm{C}-\mathrm{H}$ (Figure 7a) and C-FA and C-HA (Figure 7b). Because of the more advanced degree of stabilization in the material obtained by vermicomposting, this result was unexpected, since the action of worms alters qualitative and quantitatively the organic matter present in manures; these changes are more

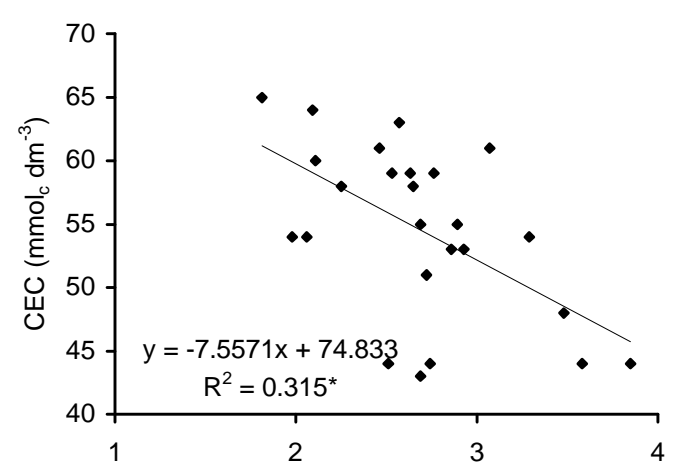

b)

$\mathrm{C}-\mathrm{HA}\left(\mathrm{g} \mathrm{dm}^{-3}\right)$

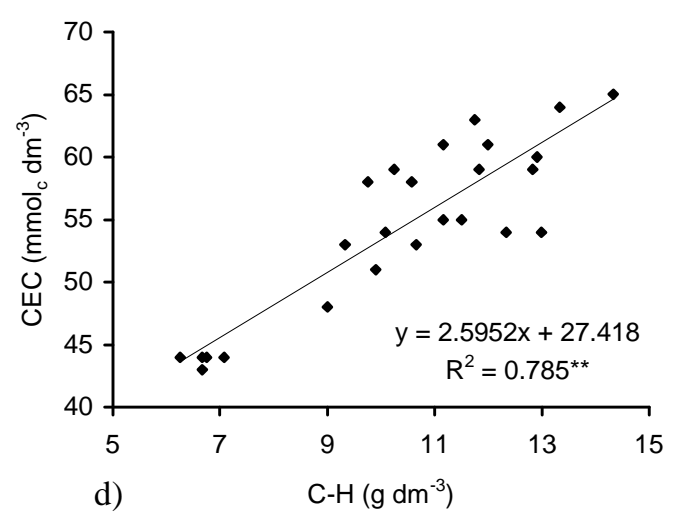

Figure 6 - Correlation between soil CEC at pH 7.0 and total carbon content a) and $\mathrm{C}$ in the humic acids b), fulvic acids c) and humin d) fractions. $*$ and $* *$ significant at $5 \%$ and $1 \%$, respectively. 

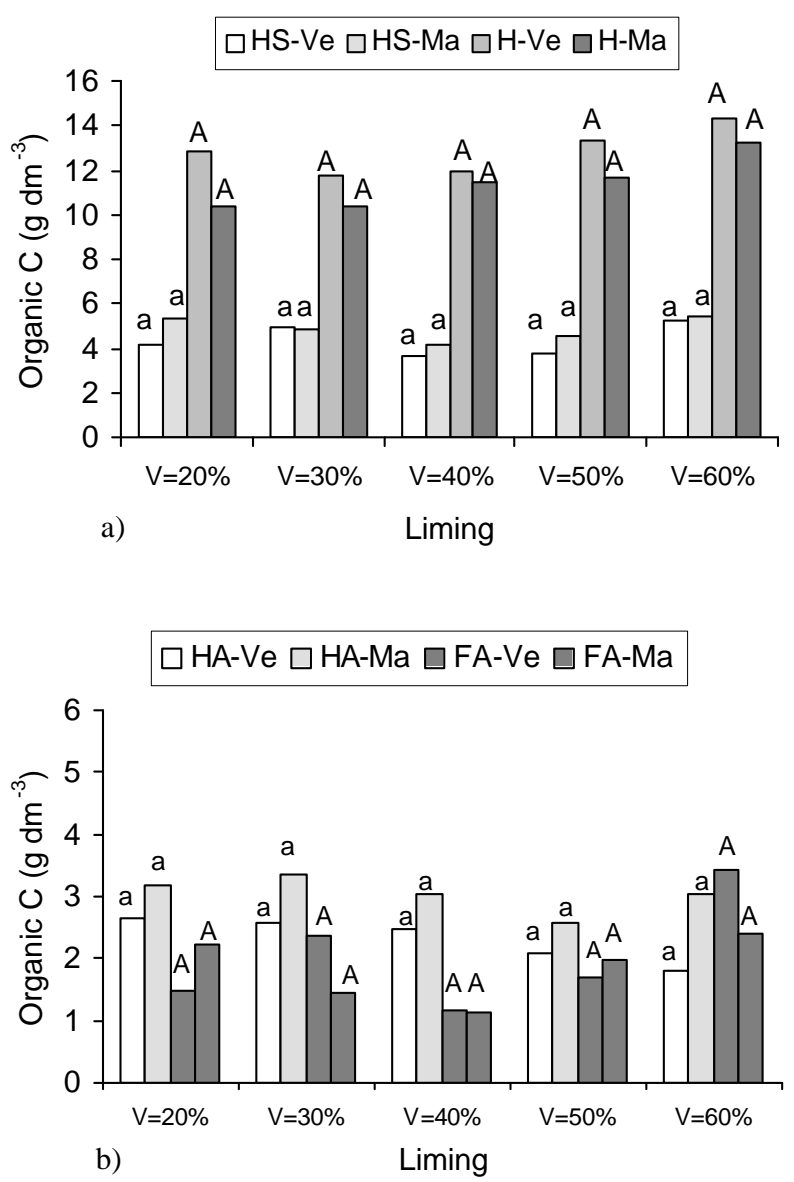

Figure 7 - Comparison of effects of application of vermicompost (Ve) and manure (Ma) on fractions $\mathrm{C}-\mathrm{HS}$ and $\mathrm{C}-\mathrm{H}$ (a) and C-HA and C-FA (b). Common upper or lower case letters indicate the absence of significant effect by Tukey test $(P<0.05)$. C: carbon; HS: humic substances; HA: humic acids; FA: fulvic acids; $\mathrm{H}$ : humin.

evident when the source of material is not very humified (Petrussi et al., 1988). On the other hand, the mean CHA contents in the soil, regardless of liming level, were smaller with the use of vermicompost (data not presented). As commented before, vermicompost and manure caused an increase in soil $\mathrm{pH}$, but the effect of the first was greater (Figure 3 ). Therefore, the smallest C-HA contents obtained with the use of vermicompost may be related to greater depolymerization of smaller-chain compounds in the HA with the greater increase in $\mathrm{pH}$ (Ghosh \& Schnitzer, 1980).

\section{REFERENCES}

ABREU Jr., C.H.; MURAOKA, T.; LAVORANTE, A.F.; ALVAREZ V.; F.C. Condutividade elétrica, reação do solo e acidez potencial em solos adubados com composto de lixo. Revista Brasileira de Ciência do Solo, v.24, p.635-647, 2000.

ALVES, W.L.; MELO,W.J.; FERREIRA, M.E. Efeito do composto de lixo urbano em um solo arenoso e em plantas de sorgo. Revista Brasileira de Ciência do Solo, v.23, p.729-736, 1999.
ARAUJO, Q.R.; FIGUEIREDO, M.S.; COSTA, L.M.; LOURES, E.G.; REGAZZI, A.J.; FONTES, L.E.F.; CASALI, V.W.D. Atividade microbiana e fracionamento da matéria orgânica em um Latossolo Vermelho-Amarelo variação una submetido à queima e à percolação. Revista Ceres, v.42, p.393-404, 1995.

CANELLAS, L.P.; SANTOS, G.A.; AMARAL SOBRINHO, N.M.B. Relações da matéria orgânica. In: SANTOS, G.A.; CAMARGO, F.A.O. (Ed.) Fundamentos da matéria orgânica do solo. Porto Alegre: Gênesis, 1999. p.69-89.

CURTIN, D.; CAMPBELL, C.A.; JALIL, A. Effects of acidity on mineralization: $\mathrm{pH}$-dependence of organic matter mineralization in weakly acidic soils. Soil Biology \& Biochemistry, v.30, p.57-64, 1998.

DABIN, B. Análises dos compostos húmicos do solo. In: COLÓQUIO SOBRE MATÉRIA ORGÂNICA DO SOLO, 1., Piracicaba, 1976. Anais. Piracicaba: USP, CENA, 1976. 55p.

FERREIRA, M.E.; CRUZ, M.C.P. Estudo do efeito de vermicomposto sobre absorção de nutrientes e produção de matéria seca pelo milho e propriedades do solo. Científica, v.20, p.217-227, 1992.

GHOSH, K.; SCHNITZER, M. Macromolecular structures of humic substances. Soil Science, v.129, p.266-276, 1980.

GLÓRIA, N.A.; CATANI, R.A.; MATUO, T. Determinação da capacidade de troca de cátions do solo por fotometria de chama. Anais da ESALQ, v.22, p.3-9, 1965.

GREENLAND, D.J. Interactions between humic and fulvic acids and clays. Soil Science, v.111, p.34-41, 1971.

HAYES, M.H.B.; MALCOLM, R.L. Considerations of compositions and of aspects of the structures of humic substances. In: CLAPP, C.E.; HAYES, M.H.B; SENESI, N.; BLOOM, P.R. JARDINE, P.M. (Ed.) Humic substances and chemical contaminants. Madison: SSSA, 2001. cap 1, p.3-39.

HUE, N.V.; CRADDOCK, G.R.; ADAMS, F. Effect of organic acids on aluminum toxicity in subsoils. Soil Science, v.50, p.28-34, 1986.

JIMÉNEZ, E.I.; GARCIA, V.P. Determination of maturity indexes for city refuse composts. Agriculture, ecosystems and environment, v.38, p.331-343, 1992.

KIEHL, E.J. Fertilizantes orgânicos. Piracicaba: Ceres, 1985. 492p.

KREUTZER, K. Effects of forest liming on soil processes. Plant and Soil, v.168-169, p.447-470, 1995.

LAL, R. World cropland soils as a source or sink for atmospheric carbon. Advances in Agronomy, v.71, p.145-191, 2001.

LOBARTINI, J.C.; ORIOLI, G.A. Las sustancias húmicas y la nutrición vegetal. Revista de la Facultad de Agronomia, v.101, p.201-209, 1996.

MARSCHNER, B.; WILCZYNSKI, A.W. The effect of liming on quantity and chemical composition of soil organic matter in a pine forest in Berlin, Germany. Plant and Soil, v.137, p.229-236, 1991.

MAZUR, N.; SANTOS, A.; VELLOSO, A.C.X. Efeito do composto de resíduo urbano na disponibilidade de fósforo em solo ácido. Revista Brasileira de Ciência do Solo, v.7, p.153-156, 1983.

MELO, W.J.; MARQUES, M.O.; SANTIAGO, G.; CHELLI, R.A.; LEITE, S.A.S. Efeito de doses crescentes de lodo de esgoto sobre frações da matéria orgânica e CTC de um latossolo cultivado com canade-açúcar. Revista Brasileira de Ciência do Solo, v.18, p.449-455, 1994.

MENDONÇA, E.S. Oxidação da matéria orgânica e sua relação com diferentes formas de alumínio de latossolos. Revista Brasileira de Ciência do Solo, v.19, p.25-30, 1995.

MENDONÇA, E.S.; ROWELL, D.L. Dinâmica do alumínio e de diferentes frações orgânicas de um latossolo argiloso sob cerrado e soja. Revista Brasileira de Ciência do Solo, v.18, p.295-303, 1994.

NASCIMENTO, V.M.; MELO, W.J.; NEPTUNE, A.M.L. Efeitos de rotação de culturas sobre frações da matéria orgânica de um latossolo sob vegetação de cerrado. Científica, v.16, p.13-19, 1988.

PICCOLO, A. The supramolecular structure of humic substances. Soil Science, v.166, p.810-832, 2001.

QUAGGIO, J.A.; RAIJ, B. van. Comparação de métodos rápidos para a determinação da matéria orgânica em solo. Revista Brasileira de Ciência do Solo, v.3, p.184-187, 1979.

PETRUSSI, F.; NOBILI, M.; VIOTTTO, M.; SEQUI, P. Characterization of organic matter from animal manure after digestion by earthworms. Plant and Soil, v.105, p.41-46, 1988 
RAIJ, B. van. Fertilidade do solo e adubação. Piracicaba: Ceres; Potafos, 1991. 343p.

RAIJ, B. van; QUAGGIO, J.A.; CANTARELLA, H.; FERREIRA, M.E.; LOPES, A.S.; BATAGLIA, O.C. Análise química do solo para fins de fertilidade. Campinas: Fundação Cargill, 1987. 170p.

RIBEIRO, A.C.; GUIMARÃES, P.T.G.; ALVAREZ V., V.H. Recomendações para o uso de corretivos e fertilizantes em Minas Gerais - 5 ${ }^{\text {a }}$ Aproximação. Viçosa. CFSEMG, 1999. 359p.

ROSALES, M.A.; OLIVEIRA, O.S.; MOURA, M.A.; LOURES, E.G. Influência das adubações orgânica e mineral contínuas sobre as características das frações das substâncias húmicas do solo. Revista Ceres, v.46, p.67-81, 1999.

SCHNITZER, M. Soil organic matter - the next 75 years. Soil Science, v.151, p.41-58, 1991.

SILVA, C.A.; ANDERSON, S.J.; GUILHERME, L.R. Uso da cromatografia de exclusão por tamanho na caracterização de substâncias húmicas de Latossolo Vermelho-Escuro sob efeito da calagem. Revista Brasileira de Ciência do Solo, v.24, p.495-503, 2000
STEVENSON, F.J. Cycles of soil: carbon, nitrogen, phosphorus, sulfur, micronutrients. New York: John Wiley \& Sons, 1986. 380p.

STEVENSON, F.J. Humus chemistry: genesis, composition, reactions. 2.ed. New York: John Wiley \& Sons, 1994. 512p.

TOMBÁCZ, E. Colloidal properties of humic acids and spontaneous changes of their colloidal state under variable solution conditions. Soil Science v.164, p.814-824, 1999 .

VARADACHARI, C.; MONDAL, A.H.; NAYAK, D.C.; GHOSH, K. Clayhumus complexation: effect of $\mathrm{pH}$ and the nature of bonding. Soil Biology \& Biochemistry, v.26, p.1145-1149, 1995.

YAGI, R.; FERREIRA, M.E.; CRUZ, M.C.P. Frações da matéria orgânica em solo arenoso tratado com vermicomposto de lixo urbano em diferentes condições de pH. (Compact disc). In: SIMPÓSIO INTERNACIONAL DE INICIAÇÃO CIENTÍFICA DA UNIVERSIDADE DE SÃO PAULO, Piracicaba, 2000. Anais. São Paulo: USP, 2000

Received May 07, 2002

Accepted April 30, 2003 